\title{
PENGARUH KOMPETENSI DAN STRESS KERJA TERHADAP KINERJA KARYAWAN PT BUSANA UTAMA TEXTILE (DEPARTEMEN SEWING)
}

\author{
Wachid Hasyim ${ }^{1}$, Isnaini Rokhmatin ${ }^{2}$ \\ 1 Universitas Pelita Bangsa, hasyimwachid2@gmail.com \\ 2 Universitas Pelita Bangsa, isnainirokhmatin5@gmail.com
}

A R T I C L E I N F O

Article history:

Received : 29/04/2021

Revised : 29/04/2021

Accepted: 29/04/2021

Key words:

Competence; Job Stress; Employee

Performance

DOI:

Doi.org/10.37366/jespb.v6i01.181

\begin{abstract}
A B S T R A C T
Human Resources is one of the most important factors in a company. It is not easy to find professional human resources to be a problem today. This is due to several factors including the level of competence and work stress that can affect employee performance. This study aims to analyze the competence and work stress on the performance of the employees of PT Busana Utama Tekstil (Sewing Department) Pekalongan. This type of research is quantitative. The population in this study were employees of PT Busana Utama Textile (Sewing Department) Pekalongan. The data were collected using saturated sampling sent to 60 respondents. The data techniques in this study were questionnaires and documentation with Multiple Linear Regression Analysis, with the help of SPSS 21 for windows software.

The results showed that competence and work stress together have a significant effect on employee performance, indicated by the value of $F$ count $=3.656>F$ table $=$ 2.54 with a significance level of $0.032<0.05$. Likewise, the partial test ( $t$ test) for the competency variable (X1) obtained the value of $t=2.177>t$ table $=2,000$ with a significance level of $0.034<0.05$, but there is a variable Job Stress (X2) which has no significant effect on employee performance by obtaining $t$ count $=0.624<t$ table $=$ 2,000 with a significance level of $0.535>0.05$. Meanwhile, the correlation between competence and work stress on employee performance obtained $R 2$ value of 0.083 or $8.3 \%$ while the remaining $91.7 \%$ was carried out by other factors outside of the study. This the criteria for companies to be able to improve performance by making improvements continuously. so that it can have a positive impact on the company.
\end{abstract}

\section{A B S T R A K}

Sumber Daya Manusia merupakan salah satu faktor terpenting dalam perusahaan. Tidak mudah mencari sumber daya manusia yang professional menjadi masalah yang dihadapi saat ini.Hal ini disebabkan beberapa faktor diantaranya tingkat kompetensi dan stress kerja yang dapat mempengaruhi kinerja karyawan. Penelitian ini bertujuan untuk menganalisis pengaruh kompetensi dan stress kerja terhadap kinerja karyawan PT Busana Utama Textile (Departemen Sewing) Pekalongan. Jenis penelitian ini adalah kuantitatif.Populasi dalam penelitian ini adalah karyawan PT.Busana Utama Textile (Departemen Sewing) Pekalongan.Pengambilan data menggunakan sampling jenuh yang didistribusikan kepada 60 responden . Teknik pengumpulan data dalam penelitian ini adalah kuisioner dan dokumentasi dengan Analisis Regresi Linier Berganda,dengan bantuan software SPSS 21 for windows.

Hasil penelitian ini menunjukkan bahwa kompetensi dan stress kerja secara bersama-sama memiliki pengaruh yang signifikan terhadap kinerja karyawan ditunjukkan nilai $F_{\text {hitung }}=3.656>F_{\text {tabel }}=2,54$ dengan taraf signifikansi 0,032< 0,05 .Demikian pula dengan uji parsial (uji t) untuk variabel kompetensi (X1) diperoleh nilai $t_{\text {hitung }}=2.177>t_{\text {tabel }}=2.000$ dengan taraf signifikansi $0,034<0,05$ ,akan tetapi terdapat variabel Stress Kerja (X2) yang tidak berpengaruh signifikan terhadap kinerja karyawan dengan diperoleh $\mathrm{t}_{\text {hitung }}=0,624<\mathrm{t}_{\text {tabel }}=$ 2.000 dengan taraf signifikansi 0,535 > 0,05 .Sedangkan besarnya hubungan Kompetensi dan Stress Kerja terhadap Kinerja Karyawan diperoleh nilai R2 sebesar 0,083 atau 8,3\% sedangkan sisanya 91,7\% dipengaruhi oleh factor lain diluar penelitian. Dengan demikian disarankan bagi perusahaan untuk dapat 
meningkatkan kinerja karyawan dengan melakukan perbaikan kompetensi secara terus menerus sehingga dapat memberikan dampak positif bagi perusahaan.

\section{PENDAHULUAN}

Pada era globalisasi seperti sekarang ini, menyebutkan terjadinya suatu pergerakan yang cepat pada bisnis. Selain itu iklim usahapun berubah sangat cepat pula. Akibat perkembangan yang cepat serta. situasi yang berubah-ubah ini, timbul berbagai peluang serta ancaman bagi dunia usaha. Salah satu faktor sumber daya yang dimiliki dan dipergunakan oleh perusahaan yang mampu mengendalikan jalannya perusahaan adalah Sumber Daya Manusia (SDM). Sumber Daya Manusia memegang peranan utama dalam proses peningkatan produktivitas kerja secara menyeluruh, karena merupakan satusatunya aset prusahaan yang hidup di samping aset-aset lain yang bersifat kebendaan seperti modal, bangunan gedung, mesin peralatan kantor, dan persediaan barang. Keunikan aset SDM ini mensyaratkan pengelolaan yang berbeda dengan aset lain, sebab aset Sumber Daya Manusia memiliki pemikiran, perasaan dan perilaku, sehingga jika dikelola dengan optimal mampu memberikan sumbangan bagi perusahaan secara aktif.

Tersedianya Sumber Daya Manusia yang profesional telah menjadi kebutuhan strategis organisasi atau perusahaan. Kebutuhan ini didasari oleh pemahaman bahwa manusia adalah penentu atas semua kinerja organisasi untuk mewujudkan Sumber Daya Manusia yang profesional bagi sebuah perusahaan kadang-kadang mengalami hambatan, dan hambatan tersebut bisa muncul dari faktor organisasi maupun dari dalam diri pegawai sendiri. Kemampuan berproduktivitas seorang pegawai sangat tergantung pada diri pegawai itu sendiri. Oleh karena itu, usaha-usaha peningkatan produktivitas kerja sebaiknya berpangkal tolak pada pegawai itu sendiri, yang merupakan fungsi utama dari fungsi manajemen, yaitu bagaimana mendorong pegawai agar mau bekerja lebih giat, kompak dan efektif. Untuk itu agar produktivitas kerja pegawai lebih meningkat, maka organisasi tempat mereka bekerja harus mampu menciptakan suasana kerja sedemikian rupa, sehingga tiap individu dapat memotivasi dari mereka sendiri untuk mau menyerahkan semua usaha produktif mereka demi kemajuan perusahaan. Jadi karakteristik individu dan pekerjaan mempunyai pengaruh langsung secara signifikan terhadap kinerja.

Menurut Mangkunegara (2013;67) kinerja adalah hasil kerja secara kualitas dan kuantitas yang dicapai seseorang pegawai dalam melaksanakan tugasnya sesuai dengan tanggung jawab yang diberikan kepadanya. Terdapat berbagai macam factor yang diduga dapat mempengaruhi kinerja karyawan diantaranya kepemimpinan, kompetensi, motivasi, budaya organisasi, beban kerja, konflik, dan stress kerja. Salah satu faktor yang ada dalam individu karyawan adalah kompetensi. Hal ini dikarenakan kompetensi merupakan salah satu modal untuk mencapai kinerja yang efektif. Wibowo (2012:324) menyatakan kompetensi adalah suatu kemampuan untuk melaksanakan atau melakukan suatu pekerjaan atau tugas yang dilandasi atas keterampilan dan pengetahuan serta didukung oleh sikap kerja yang dituntut oleh pekerjaan tersebut. Dengan demikian kompetensi menunjukan keterampilan dan pengetahuan yang dicirikan oleh profesionalisme dalam suatu bidang tertentu sebagai sesuatu yang terpenting, sebagai unggulan bidang tersebut.

Kompetensi adalah suatu kapasitas individu untuk mengerjakan berbagai tugas dalam suatu pekerjaan. Untuk dapat menyelesaikan pekerjaan dalam bidang kerja tertentu diperlukan kompetensi yang memadai. Kompetensi mempunnyai peranan yang amat penting, karena kompetensi pada umumnya menyangkut kemampuan dasar seseorang untuk melakukan suatu pekerjaan. Tanpa adanya kompetensi maka seseorang aka sulit menyelesaikan pekerjaan tersebut sesuai dengan standar yang dipersyaratkan. Oleh karenanya 
perusahaan perusahaan dapat mencapai keberhasilan apabila didukung pegawai yang berkompetensi tinggi (Robbins, 2011:46). Menurut Manopo (2011:12) kompetensi adalah kombinasi perilaku anatar pengetahuan,keterampilan dengan karakteristik yang diperlukan untuk menunjukkan peranannya dalam organisasi secara efektif dan kinerja yang sesuai di dalam organisasi . Dengan adanya sumber daya manusia yang baik, maka kompetensi yang baik akan tercipta,sehingga kinerja yang baik dapat diwujudkan dalam perusahaan tersebut.

Dari uraian tersebut dapat diketahui bahwa seorang karyawan yang unggul adalah karyawan yang menunjukan kompetensi pada skala tingkat lebih tinggi, dengan frekuensi lebih tinggi, dan dengan hasil yang lebih baik daripada karyawan biasa atau rata-rata. Oleh karenanya kompetensi merupakan karakteristik dasar yang dimiliki oleh setiap individu, yang terkait dengan kriteria yang dipersyaratkan terhadap kinerja yang unggul dan efektif. Dengan demikian dapat disimpulkan bahwa karyawan yang kompeten adalah karyawan yang penuh percaya diri karena memiliki pengetahuan sesuai bidangnya, memiliki keterampilan serta sikap positif dalam bidang pekerjaannya.

Selain masalah di atas, faktor yang dapat mempengaruhi kinerja pegawai adalah stress kerja. Stres merupakan suatu peluang bila stres itu menawarkan perolehan yang potensial. Ini bisa terlihat misalnya kinerja yang unggul yang ditunjukkan oleh seorang atlit atau penanggung dalam situasi-situasi yang "mencekam". Individu semacam itu sering menggunakan stres secara positif untuk meningkatkan kinerja mendekati maksimum mereka. Stres pekerjaan adalah suatu konsep penting dalam studi organisasional yang diperoleh dari respon karyawan disekitarnya. Stres pada tingkatan tertentu dapat mendorong munculnya kinerja yang optimal. Akan tetapi tingkat stres yang tinggi atau tingkat rendah dan berkepanjangan, dapat mendorong penurunan kinerja dari karyawan

Menurut Handoko (2011:200) stress adalah kondisi ketegangan yang mempengaruhi emosi,proses piker dan kondisi seseorang. Seorang karyawan dengan beban kerja dan konflik yang dihadapinya di lingkungan kerja,memiliki peluang besar mengalami stress kerja. Menurut Moorhead \& Griffin (2013:175) stress adalah respon adaptif seseorang terhadap rangsangan yang menempatkan tuntutan psikologis atau fisik secara berlebihan kepada orang tersebut.Beban kerja yang berlebih juga dapat menyebabkan stres, jika banyaknya pekerjaan yang ditargetkan melebihi kapasitas karyawan, akan mengakibatkan karyawan tersebut mudah lelah, sedangkan beban kerja yang berlebih bila pekerjaan tersebut sangal kompleks dan sulit, sehingga menyita kemampuan teknis dan kognitif karyawan.

Para ahli perilaku organisasi menyatakan bahwa stres kerja (work stress\} sebagai agen penyebab dari berbagai masalah fisik, mental dan output organisasi. Stress kerja dapat berpengaruh terhadap individu, masayarakat lingkungan kerja dan organisasi. Telah banyak studi yang menghubungkan stres kerja dengan berbagai variabel, semisal stres kerja dihubungkan dengan kepribadian, dan juga banyak penelitian stres kerja yang dihubungkan dengan variabel kesehatan mental, kepuasan kerja, ketidakhadiran (absensi), ketegangan, kinerja, dan sebagainya. Berdasarkan kerangka teori tersebut, maka peneliti mencoba untuk mengaplikasikannya kedalam penelitian yang dilakukan di PT Busana Utama Textile (Departemen Sewing) Pekalongan.

PT Busana Utama Textile merupakan suatu perusahaan jasa pembuatan sarung, celana, baju koko di Pekalongan yang mempunyai beberapa klien perusahaan besar seperti PT PISMATEX. Saat musim pesanan banyak karyawan dituntut untuk bisa memaksimalkan hasil produktivitasnya. Karyawan dituntut dengan jumlah pekerjaan yang telah ditargetkan dan waktu yang dibatasi. Ketika mendekati masa deadline, maka karyawan akan mudah mengalami stres, akibat tuntutan pekerjaan tersebut. Hal ini berdampak pada tekanan yang dialami karyawan sehingga dapat menimbulkan stres kerja. Berdasarkan informasi yang didapat dari hasil wawancara dengan beberapa karyawan permasalahan yang terjadi pada PT Busana Utama 
Textile (Departemen Sewing) Pekalongan antara lain:

1) Terdapat permasalahan karyawan masih kurangnya keterampilan dan kecakapannya dalam mengerjakan pekerjaannya (menjahit) karena kurangnya pengalaman kerja yang mereka miliki.

2) Target perusahaan yang sering belum tercapai.

Fenomena yang terjadi di PT Busana Utama Textile (Departemen Sewing) menunjukkan bahwa kinerja karyawan PT Busana Utama Textile (Departemen Sewing) belum sesuai yang diharapkan. Hasil penilaian kinerja pada PT Busana Utama Textile (Departemen Sewing) dapat ditunjukkan dengan grafik berikut:

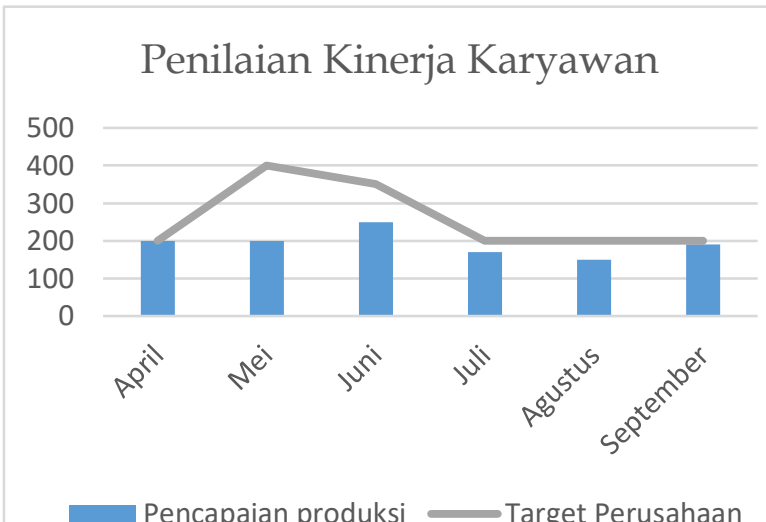

Sumber HRD PT.BUT 2020

Gambar 1. Penilaian Kinerja Karyawan

Hasil penilaian kinerja tersebut menunjukkan bahwa kecenderungan adanya grafik naik turunnya kinerja PT Busana Utama Textile (Departemen Sewing) Pekalongan dari bulan April-September 2020. Hal ini apabila dibiarkan terus menerus nantinya akan memberikan permasalahan yang serius bagi organisasi secara keseluruhan.Padahal pada proses sebelum mereka memasuki line produksi karyawan sudah diberikan pelatihan kerja selama beberapa hari agar dapat menghasilkan SDM yang kompeten. Untuk itu perlu bagi perusahaan untuk mempersiapkan langkahlangkah pemecahannya guna menghadapi kesulitan-kesulitan yang dihadapi dan memperkecil resiko akibat adanya masalah tersebut.

\section{Rumusan Masalah}

Berdasarkan uraian pada latar belakang yang telah dijabarkan di atas, maka penulis merumuskan masalah sebagai berikut:

1) Apakah ada pengaruh Kompetensi terhadap Kinerja Karyawan pada PT Busana Utama Textile (Departemen Sewing) Pekalongan?

2) Apakah ada pengaruh Stress Kerja terhadap Kinerja Karyawan pada PT Busana Utama Textile (Departemen Sewing) Pekalongan?

3) Apakah Kompetensi dan Stress Kerja terhadap Kinerja Karyawan PT Busana Utama Textile (Departemen Sewing) Pekalongan?

\section{Tujuan Penelitian}

Berdasarkan rumusan masalah di atas, maka penelitian ini bertujuan sebagai berikut:

1) Untuk mengetahui pengaruh Kompetensi terhadap Kinerja Karyawan pada PT Busana Utama Textile (Departemen Sewing) Pekalongan.

2) Untuk mengetahui pengaruh Stress Kerja terhadap Kinerja Karyawan pada PT Busana Utama Textile (Departemen Sewing) Pekalongan.

3) Untuk mengetahui Kompetensi dan Stress Kerja terhadap Kinerja Karyawan PT Busana Utama Textile (Departemen Sewing) Pekalongan.

\section{TINJAUAN TEOIRITIS}

\section{Kinerja}

Kinerja di dalam suatu organisasi dilakukan oleh segenap sumber daya manusia yang ada dalam organisasi, baik unsur pimpinan maupun pekerja. Banyak faktor yang mempengaruhi karyawan dalam menjalankan kinerjanya. Terdapat faktor yang berasal dari dalam diri karyawan maupun dari luar dirinya. Menurut amstrong dan baron dalam wibowo (2012:7) kinerja merupakan hasil pekerjaan yang memiliki hubungan kuat dengan tujuan strategi organisasi, kepuasan konsumen dan memberikan kontribusi kepada ekonomi. Menurut Mangkunegara (2013;67) kinerja adalah hasil kerja 
secara kualitas dan kuantitas yang dicapai seseorang pegawai dalam melaksanakan tugasnya sesuai dengan tanggung jawab yang diberikan kepadanya.

Menurut Smith (dalam Suwatno dan Priansa 2011:196) kinerja merupakan hasil dari suatu proses yang dilakukan manusia. Sedangkan menurut Sinambela (2012:5) kinerja pegawai didefinisikan sebagai kemampuan pegawai dalam melakukan suatu keahlian tertentu. Kinerja pegawai sangatlah perlu, sebab dengan kinerja iniakan diketahui seberapa jauh kemampuan pegawai dalam melaksanakan tugas yang dibebankan kepadanya. Sedarmayanti (2013:260) menyatakan kinerja adalah hasil kerja yang dicapai oleh seseorang atau sekelompok orang dalam suatu organisasi, sesuai dengan wewenang dan tanggung jawab masingmasing dalam rangka mencapai tujuan organisasi yang bersangkutan secara legal, tidak melanggar hukum dan sesuai denga moral maupun etika.

\section{Kompetensi}

Keberadaan manusia dalam organisasi memiliki peran yang sangat penting bagi organisasi. Hal ini dikarenakan keberhasilan suatu organisasi sangat ditentukan oleh kualitas karyawan yang bekerja di dalamnya. Pandangan ini sejalan dengan pandangan Wibowo (2012:323) yang mengatakan setiap organisasi dibentuk untuk mencapai tujuan tertentu dan apabila tercapai, barulah dapat disebut sebagai sebuah keberhasilan, untuk mencapai keberhasilan, diperlukan landasan yang kuat berupa kompetensi yang dimiliki karyawan. Selanjutnya Menurut Rivai dan Ella (2011:304) menyatakan bahwa kompetensi merupakan pengetahuan, ketrampilan dan kemampuan yang berhubungan dengan pekerjaan, serta kemampuan yang dibutuhkan untuk pekerjaan-pekerjaan non rutin. Kompetensi merupakan faktor kunci penentu bagi seseorang dalam menghasilkan kinerja yang sangat baik. Dalam situasi kolektif, kompetensi merupakan faktor kunci penentu keberhasilan sebuah organisasi. sedangkan menurut Garry Dessler (2011:169) mengatakan bahwa kompetensi sebagai karakteristik dari suatu kemampuan seseorang yang dapat dibuktikan sehingga memunculkan suatu prestasikerja atau kinerja.
Menurut Wibowo (2012:324) kompetensi adalah suatu kemampuan untuk melaksanakan atau melakukan suatu pekerjaan atau tugas yang dilandasi atas keterampilan dan pengetahuan serta didukung oleh sikap kerja yang dituntut oleh pekerjaan tersebut. Dengan demikian, kompetensi menunjukan keterampilan dan pengetahuan yang dicirikan oleh profesionalisme dalam suatu bidang tertentu sebagai sesuatu yang terpenting, sebagai unggulan bidang tersebut.

Kompetensi menurut Darsono dan Tjanjuk (2011:123) adalah perpaduan keterampilan, pengetahuan, kreativitas, dan sikap positif terhadap pekerjaan tertentu yang diwujudkan dalam kinerja. Kompetensi merupakan karakter seseorang pekerja yang mampu menghasilkan kinerja terbaik dibanding orang lain. Dalam Darsono (2011:123) kinerja orang yang berkompeten dapat dilihat dari sudut pandang:

- Kesuksesan, yaitu orang yang selalu sukses dalam bidang pekerjaan tertentu.

- Kreativitas, yaitu orang yang selalu berfikir alternative dalam memecahkan masalah dan setiap masalah yang dihadapi dapat dipecahkan.

- Inovatif, yaitu orang yang mampu menemukan sesuatu yang baru, misalkan alat kerja baru, metode kerja baru, produk baru, dan lain sebagainnya.

Dari beberapa pendapat dapat diambil kesimpulan bahwa kompetensi menunjukan karakteristik pengetahuan dan keterampilan yang dimiliki karyawan atau dibutuhkan oleh setiap individu yang memampukan karyawan untuk melakukan tugas dan tanggung jawab karyawan secara efektif dan meningkatkan standar kualitas professional dalam melakukan pekerjaan. Kompetensi SDM harus berkembang berdasarkan perubahan lingkungan kerja, struktur organisasi, dan perkembangan ilmu dan teknologi sehingga membentuk SDM yang membuat dua komponen yaitu:

- Nilai, mereka orang-orang kompeten menjunjung tinggi dan menghormati suatu nilai tertentu yang dijadikan pedoman berfikir dan bertindak secara objektif dan memiliki integritas tinggi. 
- Norma-norma, mereka orang-orang yang berkompeten memenuhi aturan-aturan yang ditetapkan oleh organisasi dimana mereka bekerja dan dimana mereka hidup dalam masyakat.

\section{Stres Kerja}

Menurut Moorhead \& Griffin (2013:175) stres adalah respons adaptif seseorang terhadap rangsangan yang menempatkan tuntutan psikologis atau fisik secara berlebihan kepada orang tersebut. Menurut Handoko (2011:200) stres adalah kondisi ketegangan yang mempengaruhi emosi, proses berpikir dan kondisiseseorang. Stres yang terlalu besar dapat mengancam kemampuan seseorang untuk menghadapi lingkungan. Sebagai hasilnya, pada diri karyawan berkembang berbagai macam gejala stres yang dapat mengganggu pelaksanaan kerja mereka. Gejala-gejala ini menyangkut baik kesehatan fisik maupun kesehatan mental.

Menurut Luthans (2011:279), stres didefinisikan sebagai suatu respon adaptif terhadap situasi eksternal yang menghasilkan penyimpangan fisik, psikologis dan atau perilaku pada anggota organisasi. Selain itu, Mangkunegara (2011:157) menyatakan bahwa stres kerja adalah perasaan tertekan yang dialami karyawan dalam menghadapi pekerjaan. Stres kerja tampak dari emosi yang tidak rileks, cemas, tegang, gugup, tekanan darah meningkat, dan mengalami gangguan pencernaan.

Dari uraian di atas dapat disimpulkan bahwa terjadinya stres kerja adalah dikarenakan adanya ketidakseimbangan antara karakteristik kepribadian pegawai dengan karakteristik aspekaspek pekerjaannya dan dapat terjadi pada semua kondisi pekerjaan. Adanya beberapa atribut tertentu dapat mempengaruhi daya tahan stres seorang pegawai.

\section{Kerangka Pikir}

Untuk menggambarkan penjabaran dari latar belakang penelitian ini dapat dituangkan dalam kerangka pemikiran sebagai berikut:

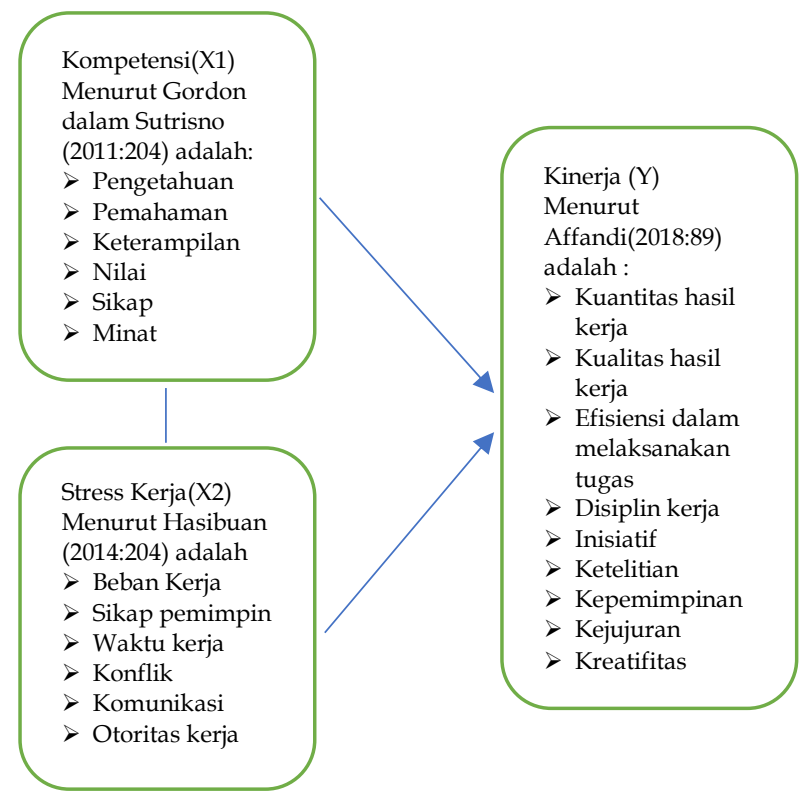

\section{Gambar 2. Kerangka Pikir}

Dari gambaran diatas dapat diajukan hipotesisnya sebagai berikut:

H1: Diduga terdapat pengaruh positif dan signifikan antara kompetensi terhadap kinerja karyawan PT Busana Utama Textile (Departemen Sewing) Pekalongan.

H2: Diduga ada pengaruh positif dan signifikan antara Stress kerja terhadap kinerja karyawan PT Busana Utama Textile (Departemen Sewing) Pekalongan

H3: Diduga ada pengaruh secara simultan antara Kompetensi dan Stress Kerja terhadap Kinerja karyawan PT Busana Utama Textile (Departemen Sewing) Pekalongan.

\section{METODE PENELITIAN}

Penelitian ini menggunakan metode kuantitaf, pengambilan data dengan metode yaitu: kuisioner, observasi, wawancara, dokumentasi, dan literatur jurnal yang berhubungan dengan variable penelitian. Setelah data terkumpul, langkah selanjutnya, dengan tahapan analisis data hypotesis dengan menggunakan analysis regresi linier berganda. Dan tempat penelitian sebagai populasi penelitian adalah PT Busana Utama Textile (Departemen Sewing) Pekalongan. 


\section{ANALISIS DAN PEMBAHASAN}

\section{Karakteristik Responden}

Tabel 1. Jenis Kelamin Karyawan

\begin{tabular}{|l|c|c|}
\hline \hline \multicolumn{1}{|c|}{ Kategori } & Frekuensi & Prosentase \\
\hline Laki-laki & 3 & 5 \\
\hline Perempuan & 57 & 95 \\
\hline Total & 60 & 100 \\
\hline \hline
\end{tabular}

Berdasarkan tabel 1 dapat diketahui bahwa karakteristik responden berdasarkan jenis kelamin karyawan PT Busana Utama Textile (Departemen Sewing) Pekalongan, sebagian besar responden adalah perempuan yaitu sebanyak 57 responden (95\%).

Tabel 2. Usia Karyawan

\begin{tabular}{|l|c|c|}
\hline Kategori & Frekuensi & Prosentase \\
\hline$<20$ tahun & 51 & 85 \\
\hline $20-30$ tahun & 7 & 11,7 \\
\hline$>30$ tahun & 2 & 3,3 \\
\hline Total & 60 & 100 \\
\hline \hline
\end{tabular}

Berdasarkan table 2 dapat diketahui bahwa karakteristik responden berdasarkan Usia Karyawan pada PT Busana Utama Textile (Departemen Sewing) Pekalongan, sebagian besar adalah responden termasuk dalam usia kurang dari 20 tahun yaitu sebanyak 51 responden (85\%).

\section{Tabel 3. Pendidikan Terakhir}

\begin{tabular}{|c|c|c|}
\hline \hline Kategori & Frekuensi & Prosentase \\
\hline SMA/SMK & 60 & 100 \\
\hline Total & 60 & 100 \\
\hline
\end{tabular}

Berdasarkan table 3 dapat diketahui bahwa karakteristik responden berdasarkan pendidikan terakhir karyawan PT Busana Utama Textile (Departemen Sewing) Pekalongan, seluruhnya berpendidikan terakhir SMA/SMK yaitu sebanyak 60 responden $(100 \%)$.

Tabel 4. Masa Kerja

\begin{tabular}{|l|c|c|}
\hline \multicolumn{1}{|c|}{ Kategori } & Frekuensi & Prosentase \\
\hline$<1$ tahun & 50 & 83,3 \\
\hline $1-2$ tahun & 8 & 13,3 \\
\hline$>2$ tahun & 2 & 3,3 \\
\hline
\end{tabular}

\begin{tabular}{|l|l|l|}
\hline Total & 60 & 100 \\
\hline
\end{tabular}

Berdasarkan tabel 4 dapat diketahui bahwa karakteristik responden berdasarkan masa kerja karyawan PT Busana Utama Textile (Departemen Sewing) Pekalongan, sebagian besar adalah responden termasuk dalam masa kerja $<1$ tahun tahun yaitu sebanyak 50 responden $(83,3 \%)$.

Uji Validitas

Tabel 5. Hasil Uji Validitas

\begin{tabular}{|c|c|r|r|r|}
\hline Variabel & & r hitung & r tabel & Ket \\
\hline \multirow{4}{*}{$\begin{array}{c}\text { Kompetensi } \\
\text { (X1) }\end{array}$} & $\mathrm{X} 1.1$ & 0,588 & 0,254 & Valid \\
\cline { 2 - 5 } & $\mathrm{X} 1.2$ & 0,590 & 0,254 & Valid \\
\cline { 2 - 5 } & $\mathrm{X} 1.3$ & 0,719 & 0,254 & Valid \\
\cline { 2 - 5 } & $\mathrm{X} 1.4$ & 0,628 & 0,254 & Valid \\
\cline { 2 - 5 } & $\mathrm{X} 1.5$ & 0,798 & 0,254 & Valid \\
\cline { 2 - 5 } & $\mathrm{X} 1.6$ & 0,656 & 0,254 & Valid \\
\hline \multirow{4}{*}{$\begin{array}{c}\text { Stress Kerja } \\
(\mathrm{X} 2)\end{array}$} & $\mathrm{X} 2.1$ & 0,770 & 0,254 & Valid \\
\cline { 2 - 5 } & $\mathrm{X} 2.2$ & 0,695 & 0,254 & Valid \\
\cline { 2 - 5 } & $\mathrm{X} 2.3$ & 0,769 & 0,254 & Valid \\
\cline { 2 - 5 } & $\mathrm{X} 2.4$ & 0,807 & 0,254 & Valid \\
\cline { 2 - 5 } & $\mathrm{X} 2.5$ & 0,636 & 0,254 & Valid \\
\cline { 2 - 5 } & $\mathrm{X} 2.6$ & 0,606 & 0,254 & Valid \\
\hline \multirow{5}{*}{$\begin{array}{c}\text { Kinerja } \\
(Y)\end{array}$} & $\mathrm{Y} 1$ & 0,466 & 0,254 & Valid \\
\cline { 2 - 5 } & $\mathrm{Y} 2$ & 0,443 & 0,254 & Valid \\
\cline { 2 - 5 } & $\mathrm{Y} 3$ & 0,582 & 0,254 & Valid \\
\cline { 2 - 5 } & $\mathrm{Y} 4$ & 0,607 & 0,254 & Valid \\
\cline { 2 - 5 } & $\mathrm{Y} 5$ & 0,400 & 0,254 & Valid \\
\cline { 2 - 5 } & $\mathrm{Y} 6$ & 0,591 & 0,254 & Valid \\
\cline { 2 - 5 } & $\mathrm{Y} 7$ & 0,612 & 0,254 & Valid \\
\cline { 2 - 5 } & $\mathrm{Y} 8$ & 0,647 & 0,254 & Valid \\
\cline { 2 - 5 } & 79 & 0,647 & 0,254 & Valid \\
\hline \hline
\end{tabular}

Hasil uji validitas menunjukkan bahwa butirbutir pertanyaan pada variabel kompetensi, stress kerja dan kinerja mempunyai hasil rhitung lebih besar darpada $r_{\text {tabel. }}$ Sehingga dapat disimpulkan bahwa seluruh pertanyaan pada ke-3 (tiga) variabel tersebut valid atau layak digunakan sebagai instrument penelitian.

\section{Uji Reabilitas}

Tabel 6. Hasil Uji Reabilitas

\begin{tabular}{|l|c|c|}
\hline \hline \multicolumn{1}{|c|}{ Variabel } & $\begin{array}{c}\text { Croncbach } \\
\text { Alpha }\end{array}$ & Ket \\
\hline Kompetensi & 0,737 & Reliabel \\
\hline Stress Kerja & 0,805 & Reliabel \\
\hline Kinerja & 0,717 & Reliabel \\
\hline \hline
\end{tabular}


Hasil uji reliabilitas menunjukkan bahwa seluruh variabel mempunyai koefisien Alpha lebih dari 0,70. Dengan begitu dapat disimpulkan semua butir-butir variabel penelitian tersebut adalah reliable dan dapat digunakan sebagai instrument penelitian.

\section{Kompetensi}

\section{Tabel 7. Distribusi Jawaban Responden}

\begin{tabular}{|c|c|c|c|c|c|c|c|}
\hline No & Pernyataan & STS & TS & $\mathrm{N}$ & S & SS & Scor \\
\hline 1 & $\begin{array}{l}\text { Saya } \\
\text { mengetah } \\
\text { ui } \\
\text { bagaiman } \\
\text { a sistem } \\
\text { proses } \\
\text { produksi } \\
\text { yang baik }\end{array}$ & $0 \%$ & $0 \%$ & $10 \%$ & $75 \%$ & $15 \%$ & $100 \%$ \\
\hline 2 & $\begin{array}{l}\text { Saya } \\
\text { dapat } \\
\text { menjelask } \\
\text { an tentang } \\
\text { langkah- } \\
\text { langkah } \\
\text { proses } \\
\text { produksi }\end{array}$ & $0 \%$ & $0 \%$ & $6,7 \%$ & $63,3 \%$ & $30 \%$ & $100 \%$ \\
\hline 3 & $\begin{array}{l}\text { Saya } \\
\text { dapat } \\
\text { menyelesa } \\
\text { ikan } \\
\text { pekerjaan } \\
\text { dengan } \\
\text { keterampi } \\
\text { lan yang } \\
\text { saya miliki }\end{array}$ & $0 \%$ & $0 \%$ & $6,7 \%$ & $68,3 \%$ & $25 \%$ & $100 \%$ \\
\hline 4 & $\begin{array}{l}\text { Saya } \\
\text { selalu } \\
\text { jujur } \\
\text { dalam } \\
\text { melaksana } \\
\text { kan } \\
\text { pekerjaan }\end{array}$ & $0 \%$ & $0 \%$ & $5 \%$ & $65 \%$ & $30 \%$ & $100 \%$ \\
\hline 5 & $\begin{array}{l}\text { Saya } \\
\text { senang } \\
\text { bekerja di } \\
\text { Perusahaa } \\
\mathrm{n} \mathrm{ini} \\
\text { karena } \\
\text { kenaikan } \\
\text { gaji dilihat } \\
\text { dari } \\
\text { seberapa } \\
\text { produktivi } \\
\text { tas } \\
\text { masing- } \\
\text { masing } \\
\text { karyawan }\end{array}$ & $0 \%$ & $0 \%$ & $3,3 \%$ & $78,3 \%$ & $18,3 \%$ & $100 \%$ \\
\hline 6 & $\begin{array}{l}\text { Saya akan } \\
\text { menyelesa } \\
\text { ikan tugas } \\
\text { yang telah } \\
\text { menjadi } \\
\text { tanggung } \\
\text { jawab saya }\end{array}$ & $0 \%$ & $0 \%$ & $2 \%$ & $36 \%$ & $62 \%$ & $100 \%$ \\
\hline
\end{tabular}

Tabel 7 menunjukkan bahwa pertanyaan paling berpengaruh adalah indikator "Sikap" dengan pertanyaan "Saya senang bekerja di Perusahaan ini karena kenaikan gaji dilihat dari seberapa tingkat produktivitas masing-masing karyawan "setuju" sebesar 78,3\%. Hal ini menunjukkan bahwa indikator yang paling baik paling berpengaruh terhadap kinerja karyawan adalah karyawan merasa senang karena kenaikan gaji dilihat dari seberapa tingkat produktivitas masing-masing karyawan sehingga karyawan akan berusaha untuk memaksimalkan pekerjaannya.

\section{Stres Kerja}

Tabel 8. Distribusi Jawaban Responden

\begin{tabular}{|c|c|c|c|c|c|c|c|}
\hline No & Pernyataan & STS & TS & $\mathrm{N}$ & $S$ & SS & Scor \\
\hline 1 & $\begin{array}{l}\text { Dengan } \\
\text { adanya beban } \\
\text { kerja berlebih } \\
\text { saya merasa } \\
\text { tertekan }\end{array}$ & $0 \%$ & $1,7 \%$ & $21,7 \%$ & $61,7 \%$ & $15 \%$ & $100 \%$ \\
\hline 2 & $\begin{array}{l}\text { Saya } \\
\text { mengalami } \\
\text { stress kerja } \\
\text { karena } \\
\text { pimpinan } \\
\text { sering } \\
\text { membedakan } \\
\text { antar } \\
\text { karyawan satu } \\
\text { dengan yang } \\
\text { lain }\end{array}$ & $0 \%$ & $1,7 \%$ & $10 \%$ & $61,7 \%$ & $26,7 \%$ & $100 \%$ \\
\hline 3 & $\begin{array}{l}\text { Saya bekerja } \\
\text { dibawah } \\
\text { tekanan waktu } \\
\text { secara terus } \\
\text { menerus }\end{array}$ & $0 \%$ & $3,3 \%$ & $13,3 \%$ & $60 \%$ & $23,3 \%$ & $100 \%$ \\
\hline 4 & $\begin{array}{l}\text { Terjadinya } \\
\text { konflik dengan } \\
\text { rekan kerja } \\
\text { membuat saya } \\
\text { susah fokus } \\
\text { dalam bekerja }\end{array}$ & $0 \%$ & $0 \%$ & $8,3 \%$ & $71,7 \%$ & $20 \%$ & $100 \%$ \\
\hline 5 & $\begin{array}{l}\text { Komunikasi } \\
\text { antar } \\
\text { karyawan yang } \\
\text { buruk dapat } \\
\text { menyebabkan } \\
\text { miss } \\
\text { komunikasi } \\
\text { dalam } \\
\text { melakukan } \\
\text { pekerjaan yang } \\
\text { sifat nya team }\end{array}$ & $0 \%$ & $0 \%$ & $1,7 \%$ & $66,7 \%$ & $31,7 \%$ & $100 \%$ \\
\hline 6 & $\begin{array}{l}\text { Saya ditekan } \\
\text { oleh banyak } \\
\text { peraturan dari } \\
\text { pimpinan }\end{array}$ & $0 \%$ & $0 \%$ & $1,7 \%$ & $73,3 \%$ & $25 \%$ & $100 \%$ \\
\hline
\end{tabular}

Tabel 8 menunjukkan bahwa pertanyaan paling berpengaruh adalah indikator "Otoritas Kerja" dengan pertanyaan "Saya ditekan oleh banyak peraturan dari pimpinan" yang menjawab "setuju" sebesar 73,3\%. Hal ini menunjukkan bahwa indikator yang paling berpengaruh terhadap kinerja karyawan adalah karyawan merasa ditekan oleh 
peraturan perusahaan yang mungkin dapat menyebabkan stress kerja.

\section{Kinerja}

Tabel 9. Distribusi Jawaban Koresponden

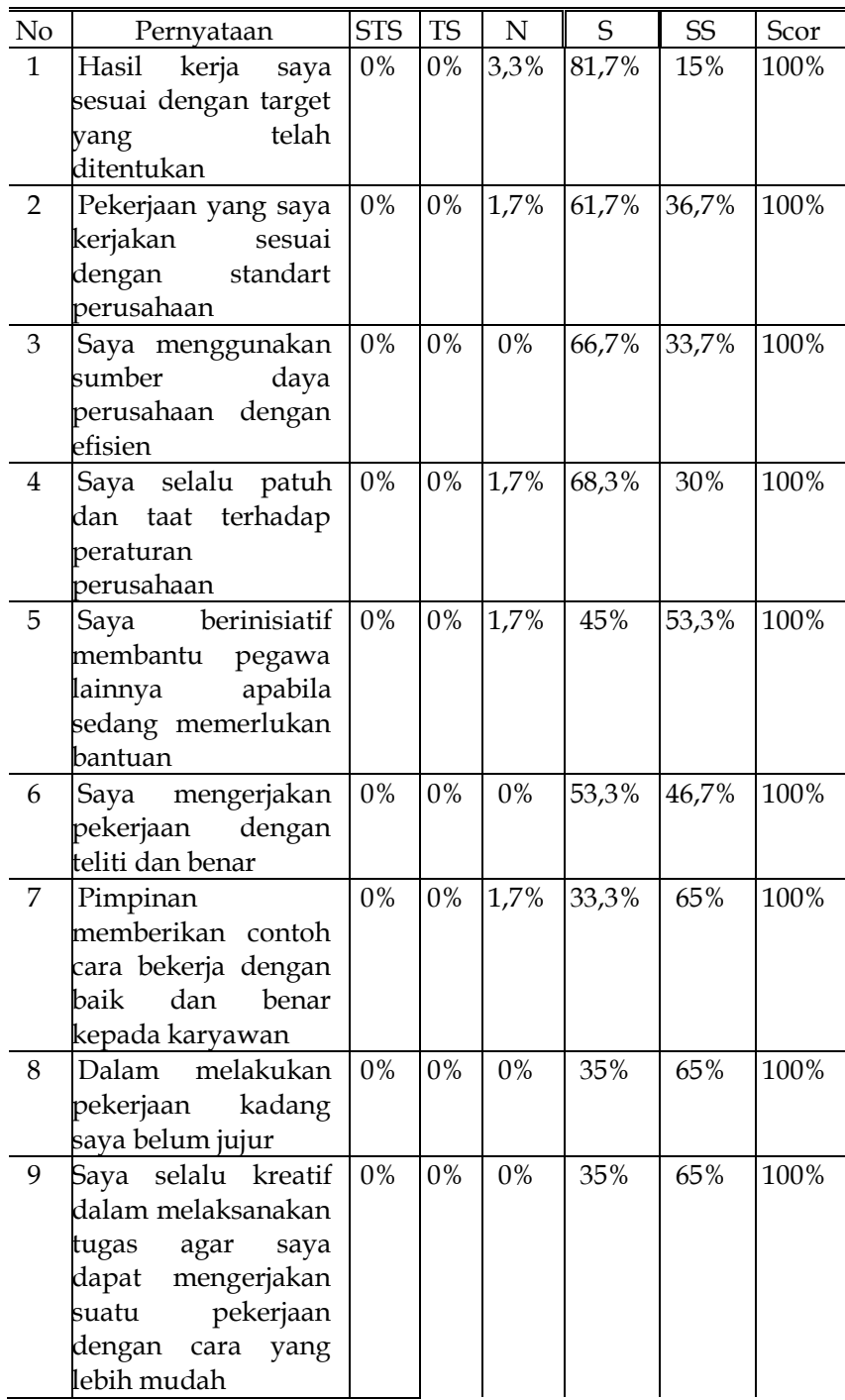

Tabel 9 menunjukkan bahwa pertanyaan paling berpengaruh adalah indikator "Kuantitas hasil kerja" dengan pertanyaan "Hasil kerja saya sesuai dengan target yang telah ditentukan" yang menjawab "sangat" sebesar $81,7 \%$. Hal ini menunjukkan bahwa para karyawan mampu bekerja secara maksimal dengan target yang telah ditentukan perusahaan.

\section{Uji Normalitas}

Tabel 10. Hasil Uji Normalitas

One-S Sample Kolmogorov-Smirnov Test

\begin{tabular}{|ll|r|}
\hline & & Unstandardized Residual \\
\hline Normal Parametersa,b & Mean & 60 \\
& Std. Deviation & .0000000 \\
& Absolute & 2.30603536 \\
& & .091 \\
Most Extreme Differences & Positive & .071 \\
& Negative & -.091 \\
Kolmogorov-Smirnov Z & & .702 \\
Asymp. Sig. (2-tailed) & & .708 \\
\hline
\end{tabular}

a. Test distribution is Normal.

b. Calculated from data.

Berdasarkan tabel $10 \mathrm{di}$ atas dapat diketahui nilai asymp.sig sebesar 0,708 $>0,05$, sehingga dapat disimpulkan bahwa data berdistribusi normal.

\section{Uji Multikolinieritas}

Tabel 11. Hasil Uji Multikolinieritas

\begin{tabular}{|l|r|c|}
\hline Model & \multicolumn{2}{|c|}{$\begin{array}{c}\text { Collinearity } \\
\text { Stastistics }\end{array}$} \\
\hline (Constant) & Tolerance & VIF \\
\hline Kompetensi & .847 & 1.181 \\
\hline Stress Kerja & .847 & 1.181 \\
\hline \hline
\end{tabular}

Berdasarkan table 11 di atas, dapat diketahui bahwa nilai tolerance $>0,10$ dan VIF $<10$, dengan demikian model yang diajukan dalam penelitian ini tidak terjadi multikoliniaritas.

\section{Regresi Linier Berganda}

\begin{tabular}{|r|r|r|r|r|r|}
\hline \multicolumn{1}{|c|}{ Coefficients $^{\mathrm{a}}$} \\
& $\begin{array}{r}\text { Unstandardized } \\
\text { Coefficients }\end{array}$ & $\begin{array}{c}\text { Standardized } \\
\text { Coefficients }\end{array}$ & $\mathrm{t}$ & Sig. \\
\cline { 2 - 7 } & \multicolumn{1}{|c|}{$\mathrm{B}$} & Std. Error & Beta & & \\
\hline $\begin{array}{r}\text { (Constant) } \\
\text { kompetensi }\end{array}$ & 29.095 & 4.112 & & 7.076 & .000 \\
stress kerja & .353 & .162 & .295 & 2.177 & .034 \\
.131 & .082 & .624 & .535 \\
\hline
\end{tabular}

a. Dependent Variable: kinerja 
Berdasarkan tabel di atas perhitungan regresi linier berganda denggan menggunakan progam SPSS versi 21.0 for windows didapat hasil sebagai berikut:

$$
\mathrm{Y}=29.095+0,353 \mathrm{X} 1+0,082 \mathrm{X} 2+\mathrm{e}
$$

1) Konstanta $=29.095$

Artinya jika tidak ada variabel kompetensi dan stress kerja yang mempengaruhi kinerja karyawan, maka nilai dari variabel kinerja sudah meningkat sebesar 29.095.

2) $\mathrm{b} 1=0,353$

Artinya apabila terdapat kenaikan 1 poin pada variabel kompetensi dan variabel yang lain dianggap tetap, maka akan terjadi peningkatan pada variabel kinerja sebesar 0,353.

3) $b 2=0,082$

Artinya apabila terdapat kenaikan 1 poin pada variabel stress kerja dan variabel lain dianggap tetap, maka akan terjadi peningkatan pada variabel kinerja sebesar 0,082 .

\section{Uji Parsial (Uji t)}

Berdasarkan hasil uji regresi linier berganda pembahasan hasil uji t adalah sebagai berikut:

1) Pengaruh Kompetensi (X1) terhadap Kinerja Karyawan (Y)

Berdasarkan hasil secara parsial, Variabel Kompetensi berpengaruh positif dan signifikan secara parsial terhadap kinerja karyawan, hal ini terlihat dari thitung (2.177) $>t_{\text {tabel }}(2.000)$ dan signifikan $(0,034)<0,05$. Dengan demikian dapat diambil kesimpulan bahwa Ho ditolak dan $\mathrm{H}_{\mathrm{a}}$ diterima.

2) Pengaruh Stress Kerja ( $X 2)$ terhadap Kinerja Karyawan (Y)

Berdasarkan hasil secara parsial, Variabel Stress Kerja tidak berpengaruh positif dan signifikan secara parsial terhadap kinerja karyawan, hal ini terlihat dari thitung $(0,624)<t_{\text {tabel }}(2.000)$ dan signifikan $(0,535)>0,05$. Dengan demikian dapat diambil kesimpulan bahwa $\mathrm{H}_{\mathrm{O}}$ diterima dan $\mathrm{H}_{\mathrm{a}}$ ditolak.

\section{Uji Simultan (Uji F)}

\begin{tabular}{|c|c|c|c|c|c|}
\hline \multicolumn{6}{|c|}{ ANOVA $^{a}$} \\
\hline Model & Sum of Squares & $\mathrm{df}$ & Mean Square & $\mathrm{F}$ & Sig. \\
\hline Regression & 40.250 & 2 & 20.125 & 3.656 & $.032^{b}$ \\
\hline 1 Residual & 313.750 & 57 & 5.504 & & \\
\hline Total & 354.000 & 59 & & & \\
\hline
\end{tabular}

a. Dependent Variable: kinerja

b. Predictors: (Constant), stress kerja, kompetensi

Berdasarkan tabel di atas hasil uji $\mathrm{F}$ diperoleh $F_{\text {hitung }}>\mathrm{F}_{\text {tabel }}(3.656>2,54)$ dan probabilitas sebesar $0,032<0,05$. Karena sig $F_{\text {hitung }}<5 \%(0,032<0,05)$ maka dapat disimpulkan bahwa terdapat pengaruh kompetensi dan stress kerja secara simultan terhadap kinerja karyawan PT Busana Utama Textile (Departemen Sewing) Pekalongan.

\section{Koefisian Determinasi (Adjusted $\mathbf{R}^{2}$ )}

\begin{tabular}{|l|c|r|r|c|}
\hline Model & $\mathrm{R}$ & R Square & $\begin{array}{c}\text { Adjusted R } \\
\text { Square }\end{array}$ & $\begin{array}{c}\text { Std. Error of the } \\
\text { Estimate }\end{array}$ \\
\hline 1 & \multicolumn{1}{|c|}{ Modia } & .114 & .083 & 2.346 \\
\hline
\end{tabular}

a. Predictors: (Constant), stress kerja, kompetensi

Berdasarkan table di atas menunjukkan besarnya koefisiensi determinasi (Adjusted $R^{2}$ ) = 0,083 artinya variabel bebas secara bersama-sama mempengaruhi variabel tidak bebas sebesar 8,3\% sisanya sebesar $91,7 \%$ dipengaruhi oleh variabel lain yang tidak dimasukkan dalam model penelitian. Jadi, kompetensi dan stress kerja akan berpengaruh secara bersama-sama terhadap kinerja. Hal tersebut dilakukan dengan cara apabila kompetensi dan stress kerja dapat terkendali akan mampu memberikan dampak positif terhadap kinerjanya sesuai apa yang diterapkan oleh perusahaan tersebut. Namun, apabila apabila kompetensi dan tingkat stress kerja yang dialami tinggi akan memberikan dampak negatif terhadap kinerjanya.

\section{Pembahasan}

1) Pengaruh Kompetensi terhadap kinerja karyawan PT Busana Utama Textile (Departemen Sewing) 
Berdasarkan hasil pengujian signifikan menunjukkan bahwa terdapat nilai probilitas sebesar $0,34(0,034<0,05)$. Nilai tersebut dapat membuktikan $\mathrm{H}_{\mathrm{a} 1}$ diterima, yang berarti bahwa "Kompetensi berpengaruh signifikan terhadap kinerja karyawan PT Busana Utama Textile (Departemen Sewing) Pekalongan". Hal ini menunjukkan bahwa dengan semakin tinggi kompetensi yang dimiliki karyawan maka akan mampu meningkatkan kualitas kerja karyawan dan meningkatkan kinerja karyawan.

Hasil penelitian ini sejalan dengan yang dilakukan oleh Eigis Yani Pramularso (2018) menemukan bukti empiris bahwa kompetensi berpengaruh positif terhadap kinerja karyawan $\mathrm{CV}$ Inaura Anugerah Jakarta. Dalam menjalankan pekerjaannya setiap karyawan tentu memiliki kompetensi yang dapat diandalkan.Kompetensi menjadi bekal dan modal bagi karyawan untuk bekerja secara professional. Kompetensi ini harus terus diasah dan ditingkatkan bagi karyawan sehingga kontribusi karyawan terhadap perusahaan ke depan menjadi semakin baik lagi.

2) Pengaruh Stress Kerja terhadap Kinerja Karyawan PT Busana Utama Textile (Departemen Sewing) Pekalongan

Berdasarkan hasil pengujian signifikansi menunjukkan bahwa terdapat nilai probabilitas sebesar 0,535 $(0,535>0,05)$. Nilai tersebut dapat membuktikan $\mathrm{H}_{\mathrm{a}}$ ditolak yang berarti bahwa "Stress Kerja tidak mempunyai pengaruh secara signifikan terhadap kinerja karyawan PT Busana Utama Textile (Departemen Sewing) Pekalongan.

Hal ini sejalan dengan penelitian yang dilakukan oleh Firli Bariroh, Sri hastari, Joes Dwiharto yang menyatakan bahwa tidak terdapat pengaruh secara signifikan antara variabel stress kerja terhadap kinerja karyawan PT POS Indonesia (PERSERO) Kota Pasuruan.

3) Pengaruh Kompetensi dan Stress Kerja secara simultan terhadap kinerja karyawan PT Busana Utama Textile (Departemen Sewing) Pekalongan
Berdasarkan hasil pengujian dengan uji $\mathrm{F}$ diperoleh nilai $F_{\text {hitung }}$ sebesar 3.656 dan probabilitas sebesar 0,032. Karena sig $\mathrm{F}_{\text {hitung }}<5 \%$ $(0,032<0,05)$ maka $\mathrm{H}_{a}$ diterima atau dapat disimpulkan bahwa terdapat pengaruh kompetensi dan stress kerja secara simultan terhadap kinerja karyawan PT Busana Utama Textile (Departemen Sewing) Pekalongan.

Hal ini sejalan dengan penelitian yang dilakukan oleh R.J Rurimpunu (2018) menyatakan bahwa terdapat pengaruh kompetensi dan stress kerja secara simultan mempunyai pengaruh terhadap kinerja pegawai di Dinas Pendidikan Provinsi Sulawesi Utara.

\section{KESIMPULAN DAN SARAN}

\section{Kesimpulan}

Berdasarkan analisis data dan pembahasan yang dilakukan, maka dapat diperoleh kesimpulan sebagai berikut:

1) Dari hasil uji Instrument yang meliputi uji validitas dan uji reliabilitas serta uji asumsi klasik yang meliputi uji normalitas, uji multikolinieritas menunjukkan bahwa semua data variabel bebas terdistribusi secara normal dan tidak ditemukan adanya kolerasi antar variabel bebas (tidak terjadinya multikolinieritas.

2) Hasil pengujian hipotesis $\mathrm{H} 1$ menunjukkan bahwa terdapat nilai probabilitas sebesar 0,034 $(0,034<0,05)$. Nilai tersebut dapat membuktikan $\mathrm{H}_{\mathrm{a} 1}$ diterima, yang berarti bahwa "Terdapat pengaruh secara signifikan antara variabel bebas Kompetensi (X1) terhadap Kinerja Karyawan PT Busana Utama Textile (Departemen Sewing) Pekalongan".

3) Hasil pengujian hipotesis $\mathrm{H} 2$ menunjukkan bahwa nilai probabilitas sebesar 0,535 (0,535 > 0,05). Nilai tersebut dapat membuktikan $\mathrm{H}_{\mathrm{a} 2}$ ditolak, yang berarti bahwa "Tidak terdapat pengaruh secara signifikan antara variabel Stress Kerja (X2) terhadap Kinerja Karyawan PT Busana Utama Textile (Departemen Sewing) Pekalongan. 
4) Hasil uji $F$ diperoleh Fhitung sebesar 3.656 dan probabilitas sebesar 0,032. Karena sig Fhitung < $5 \%(0,032<0,05)$, maka $\mathrm{H}_{\mathrm{a} 3}$ diterima atau dapat disimpulkan bahwa terdapat pengaruh secara simultan antara variabel bebas Kompetensi (X1) dan Stress Kerja (X2) terhadap Kinerja Karyawan PT Busana Utama Textile (Departemen Sewing) Pekalongan.

\section{Saran}

Adapun saran bagi peneliti selanjutny bahwa dalam penelitian ini diketahui terdapat satu variabel yang berpengaruh secara signifikan terhadap kinerja yaitu kompetensi dan satu variabel yang tidak mempunyai pengaruh secara signifikan terhadap kinerja yaitu stress kerja pada PT Busana Utama Textile (Departemen Sewing) Pekalongan maka untuk peneliti selanjutnya sebaiknya peneliti mencari variabel lain yang lebih memberikan konstribusi terhadap kinerja karyawan PT Busana Utama Textile (Departeme Sewing) Pekalongan.

\section{DAFTAR PUSTAKA}

Dina Rande. (2016). "Pengaruh Kompetensi terhadap Kinerja Karyawan pada Dinas Perhubungan Komunikasi dan Informasi Kabupaten Mamuju Utara". Jurnal Katalogis. Vol.4 No.2 hal 101-109.

Ghozali, Imam (2011). Aplikasi Analisis Multivariate dengan Progam IBM SPSS 19 Edisi 5. Semarang: Badan Penerbitan Universitas Diponogoro.

Hasibuan, Malayu S.P. (2014). Manajemen Sumber Daya Manusia,Edisi Revisi. Jakarta: Bumi Aksara.

Handoko, T.Hani. (2011). Manajemen Personalia dan Sumber Daya Manusia. Yogyakarta: Penerbit BPFE.

Hasibuan, Malayu. (2012). Manajemen Sumber Daya Manusia. Jakarta: PT Bumi Aksara.

Lucia Nurbaiti Kartika. (2014). "Pengaruh Tingkat Kompetensi terhadap Kinerja Pegawai Administrasi Perkantoran". Jurnal Ekonomi dan Bisnis, Vol XVII No.1 hal 87.

Luthans, F. (2012). Perilaku Organisasi. Jakarta: Penerbit Andi.
Mangkunegara, Anwar Prabu. (2013). Mananjemen Suber Daya Manusia Perusahaan. Bandung: PT Remaja Rosdakarya.

Manopo, Christine. (2011). Competency Based Talent and Performance Management System. Jakarta: Salemba Empat.

Moorhead dan Griffin. (2013). Perilaku Organisasi. Jakarta: Salemba Empat.

Rurimpunu, Ridel Clif Joune. (2015). "Pengaruh Kompetensi dan Stress Kerja terhadap Kinerja Pegawai pada Dinas Pendidikan Nasional Provinsi SULUT". Jurnal EMBA Vol 3 No.3 hal. 3366.

Rivai, Veithal dan Ella Zauvani Sagala. (2011). "Manajemen Sumber Daya Manusia untuk Perusahaan", Edisi 2. Jakarta: Rajawali Pers.

Robbins dan Judge. (2011). Perilaku Organisasi, Edisi 12. Jakarta: Salemba Empat.

Siswandoko, Tjanjuk, dan Darsono. (2012). "Sumber Daya Manusia abad 21". Jakarta: Nusantara Consulting.

Sinambela, Lijan Poltak. (2012). Kinerja Pegawai. Yogyakarta: Graha Ilmu

Sedarmayanti. (2013). Manajemen Sumber Daya Manusia, Reformasi Birokrasi dan Manajemen Pegawai Negeri Sipil". Bandung: Refika Aditama.

Sutrisno, Edy. (2011). Manajemen Sumber Daya Manusia. Jakarta: Kencana.

Sugiyono. (2017). Metode Penelitian Kuantitatif, Kualitatif dan RED. Bandung: Alfabeta, CV.

Tri Wartono. (2017). Pengaruh stress kerja terhadap kinerja karyawan (Studi Kasus pada karyawan Majalah Mother and Baby). Jurnal Ilmiah Prodi Mananjemen Universitas Pamulang Vo.4 No.2 hal 53.

Wibowo. "Manajemen Kinerja". (2012). Jakarta: PT Raja Grafindo Ed 3.

Widodo, Suparno Eko. (2015). Manajemen Sumber Daya Manusia. Yogyakarta: Pustaka Pelajar. 
Widodo. (2017). Metodelogi Penelitian Populer dan Praktis. Jakarta: PT.Rajawali Pers.

Wibowo. (2014). Manajemen Kinerja, Edisi keempat. Jakarta: Rajawali Pers.
Yuliana. (2017). "Pengaruh Kompetensi dan Motivasi terhadap Kinerja Karyawan PT Haluan Star Logistic". Jurnal Ilmiah Manajemen Bisnis Vol.17 No.2 hal.148. 